\title{
KAJIAN KOMPOSISI LIGNIN DAN SELULOSA DARI \\ LIMBAH KAYU SISA DEKORTIKASI RAMI DAN CANGKANG KULIT KOPI UNTUK PROSES GASIFIKASI DOWNDRAFT
}

\section{A Study of Lignin and Cellulose Composition from Waste from Rami Decortication and Coffee Shell for Downdraft Gasification Process}

\author{
${ }^{1}$ Veni Aprilia Lestari dan ${ }^{2}$ Trisaksono Bagus Priambodo \\ ${ }^{1)}$ Program Studi Sarjana Biologi , Fakultas Matematika dan Ilmu Pengetahuan Alam, \\ Universitas Padjadjaran \\ ${ }^{2)}$ Pusat Teknologi Sumberdaya Energi dan Industri Kimia, BPPT \\ Badan Pengkajian dan Penerapan Teknologi (BPPT) \\ Gedung 625 Kawasan PUSPIPTEK Serpong - Tangerang Selatan 15314 \\ Email: trisaksono@bppt.go.id
}

Diterima: 16 April 2020; Diperiksa: 8 Mei 2020; Revisi: 25 Mei 2020; Disetujui: 8 Juni 2020

\begin{abstract}
Gasification of biomass can be used to produce fuel gas that could potentially be used as a power source for the sustainable development. The main aim of this study is to determine the effect of lignin, cellulose, proximate and ultimate of ramie wood chip biomass and shell coffee to produce gas and the potential for regional electricity generated. Research carried out by the analysis of lignin and cellulose, proximate and ultimate, calorific value, gasification, composition gases and energy potential. From the research results, the waste of coffee shells and ramie wood chips were used as a new energy source to produce syngas by means of the gasification process. The highest lignin content was for $45.10 \%$ coffee shell and the lowest for flax wood chips was 18.26. Meanwhile, the highest cellulose content was hemp wood chips $44.82 \%$ and the lowest was coffee skin shell $17.93 \%$. The potential energy produced from gasified gas provides a correlation with levels of lignin and cellulose. The higher the lignin content and the greater the cellulose content, the higher energy that occurs in the coffee shell shells of $5.78 \mathrm{~kW}$, and vice versa what happens to hemp wood chips with low lignin levels and high cellulose content provides a potential energy of $4.64 \mathrm{~kW}$.
\end{abstract}

Keywords: coffee shell, downdraft, gasification, lignin, cellulose, ramie wood chip

\begin{abstract}
Abstrak
Gasifikasi biomassa dapat digunakan untuk menghasilkan gas mampu bakar yang berpotensi dijadikan sumber listrik, mendukung pembangunan berkelanjutan. Tujuan penelitian ini untuk mengetahui pengaruh lignin, selulosa, komposisi proksimat dan ultimat dari biomassa chip kayu rami dan cangkang kulit kopi terhadap komposisi gas dan potensi listrik daerah yang dihasilkan. Penelitian dilakukan dengan tahapan pengujian kadar lignin dan selulosa, analisis proksimat dan ultimat, serta nilai kalor, tahapan gasifikasi, dan tahapan pengujian komposisi gas dan potensi energi. Dari hasil penelitian maka, limbah cangkang kulit kopi dan chips kayu rami dimanfaatkan menjadi sumber energi baru untuk menghasilkan syngas dengan cara proses gasifikasi. Kadar lignin tertinggi adalah untuk cangkang kulit kopi $45,10 \%$ dan terendah chips kayu rami 18,26. Sedangkan kadar selulosa tertinggi adalah chips kayu rami $44,82 \%$ dan terendah adalah cangkang kulit kopi $17,93 \%$. Potensi energi yang dihasilkan dari gas hasil gasifikasi memberikan korelasi terhadap kadar lignin dan selulosa. Semakin tinggi kadar lignin dan semakin besar kadar selulosa, maka memberikan energi yang lebih tinggi yang terjadi pada cangkang kulit kopi sebesar $5,78 \mathrm{~kW}$, dan sebaliknya yang terjadi pada chips kayu rami dengan kadar lignin rendah dan kadar selulosa tinggi memberikan potensi energi sebesar 4,64 kW.
\end{abstract}

Kata kunci: cangkang kulit kopi, downdraft, gasifikasi, lignin, selulosa, chip kayu rami

\section{PENDAHULUAN}

Indonesia sebagai negara agraris, mempunyai sumber energi biomassa yang melimpah, misalnya limbah perkebunan berupa limbah kayu sisa dekortikasi rami (chip kayu rami) dan cangkang kulit kopi. Chip kayu rami dihasilkan dari Sentra Industri Rami dengan produktivitas rami sekitar 90 ton rami per herktar per tahun (Wulandari, 2015). 
Rami merupakan tanaman yang bisa tumbuh di dataran rendah maupun perbukitan dengan ketinggian 100-500 meter diatas permukaan laut. Serat rami merupakan bahan untuk kain berkualitas tinggi dan bahan pembuatan selulosa berkualitas tinggi. Kayu dan serat rami dapat diolah menjadi pulp berkualitas tinggi sebagai bahan baku pembuatan aneka jenis kertas berharga (Purwati, 2010). Rami merupakan tanaman yang memiliki kandungan selulosa relatif tinggi, yakni sekitar $50-60 \%$, sedangkan kadar ligninnya sekitar $30 \%$ (Buri-Saroso dkk., 1999). Kadar lignin dari lignoselulotik bahan bakar umumnya memiliki korelasi dengan nilai kalor, dimana nilai kalor yang tinggi dipengaruhi oleh kadar lignin yang tinggi (Khan et al.,2008), sehingga berpotensi untuk dimanfaatkan sebagai bahan bakar alternatif.

Limbah cangkang kulit kopi merupakan limbah organik padat yang dihasilkan dari perkebunan kopi ataupun dari pabrik pengolahan kopi menjadi biji kopi. Dari data statistik, produksi biji kopi di Indonesia mencapai 666.992 ton/tahun (Badan Pusat Statistik, 2017). Dari penelitian Widyotomo , 2013, maka limbah yang dihasilkan berupa kulit kopi untuk tiap ton kopi sebesar $20 \%$. Sehingga limbah kulit kopi pada tahun 2017 sebesar 133.398 ton. Cangkang kulit kopi mempunyai kandungan lignin lebih tinggi dibandingkan selulosa, yaitu $52,59 \%$ (Purnomo, 2010).

Lignin merupakan komponen kimia dan karakteristik morfologi dari jaringan tumbuhan tinggi, terdapat dalam jaringan vaskuler yang khusus untuk pengangkutan cairan dan memberikan kekuatan mekanik sedemikian rupa sehingga tumbuhan yang besar seperti pohon tetap dapat berdiri kokoh (Fengel and Wagener, 1984). Struktur molekul lignin sangat berbeda bila dibandingkan polisakarida karena terdiri atas sistem aromatik yang tersusun atas unit-unit fenilpropana : unit guaiacyl (G) dari prekusor transkoniferil alcohol, unit syringyl (S) dari prekusor trans-p-koumaril alcohol (Palonen, 2004). Lignin dan selulosa merupakan penyusun utama suatu tumbuhan dan termasuk komposisi kimia suatu biomassa. Komposisi kimia biomassa yang lain yaitu meliputi komposisi proksimat dan ultimat. Komposisi proksimat terdiri dari nilai kalor, kadar air, kadar abu, kadar zat mudah menguap, kadar karbon terikat, dan komposisi proksimat diuji dengan menggunakan analisis proksimat, sedangkan komposisi ultimat terdiri dari kandungan Karbon (C), Hidrogen $(\mathrm{H})$, Oksigen $(\mathrm{O})$, Nitrogen (N), dan Sulfur (S) yang diuji dengan analisis ultimat. Pengaruh komposisi kimia pada proses gasifikasi, yaitu melalui kadar lignin dan selulosa akan memengaruhi kandungan unsur karbon (C.).

Gasifikasi merupakan proses konversi secara termal bahan bakar padat menjadi gas. Efisiensi yang dapat dicapai dengan teknologi gasifikasi sekitar $30-40 \%$, lebih tinggi dari teknologi pembakaran biasa. Tujuan dari gasifikasi adalah untuk memutuskan ikatan dari molekul komplek ini menjadi gas yang sederhana, yaitu hidrogen dan karbon monoksida $\left(\mathrm{H}_{2}\right.$ dan $\left.\mathrm{CO}\right)$. Kedua gas ini merupakan gas yang mudah terbakar serta memiliki potensi energi yang dapat dikonversi menjadi energy listrik. Dari beberapa penelitian yang telah dilakukan, pengaruh kandungan air terhadap efisiensi proses gasifikasi pada reaktor downdraft yaitu semakin rendah kandungan air maka efisiensi gasifikasi yang dihasilkan semakin tinggi dan nilai kapasitas listrik yang terpasang semakin besar (Kumar et al. 2014). Pemilihan reaktor gasifikasi jenis downdraft didasarkan pada rendahnya kandungan tar yang dihasilkan lebih rendah dibandingkan jenis updraft (Affendi dkk., 2010). Keuntungan lainnya dalam penggunaan reaktor gasifikasi dengan tipe reaktor downdraft adalah gas yang dihasilkan relative lebih bersih (Purnomo, 2012) dan rendahnya tingkat produksi abu arang (charcoal) serta tar hasil dari pembakaran dan kemampuannya untuk menyesuaikan diri dengan besarnya jumlah udara masukan (Rajvanshi, 2014).

Penelitian yang menggunakan gasifikasi downdraft dengan bahan bakar limbah kulit biji kopi, yang meneliti aspek distribusi temperatur, didapatkan semakin besar kecepatan aliran udara, maka terjadi peningkatan temperature dalam reaktor, sehingga menyebabkan peningkatan konsumsi biomassa yang digunakan baik untuk reaksi oksidasi, pirolisis maupun reduksi (Arisanty dkk., 2009). Sedangkan Brebu dan Vasile, 2010 melakukan penelitian mengenai mekanisme degradasi lignin pada proses pirolisis, hasilnya adalah senyawa kimia yang membentuk lignin akan menghasilkan gas melalui proses pirolisis. Kandungan kimia bahan baku telah dilaporkan oleh beberapa peneliti akan mempengaruhi proses gasifikasi, diantaranya yaitu kandungan lignin yang rendah akan membuat berat kering biomassa menjadi cukup tinggi sehingga produksi energi panas akan rendah. Sebaliknya kandungan lignin yang tinggi akan menurunkan energi panas yang dihasilkan, konversi lignin akan mempengaruhi arang yang dihasilkan (Barmina et al., 2013). Lignin mempengaruhi produksi fase uap dan nilai kalor yang dihasilkan (Giudicianni et al., 2013), kandungan lignin dan selulosa yang tinggi akan menyebabkan kadar karbon terikat yang tinggi pula sehingga nilai kalor yang dihasilkan akan tinggi sebab komponen penyusun lignin dan selulosa sebagian besar adalah karbon.

\section{BAHAN DAN METODE}

\subsection{Bahan}

Bahan yang digunakan dalam penelitian ini adalah aquades, $\mathrm{H}_{2} \mathrm{SO}_{4} 1 \mathrm{~N}, \mathrm{H}_{2} \mathrm{SO}_{4} 72 \%$, kertas saring, larutan indikator $\mathrm{MO}$, larutan $\mathrm{Na}_{2} \mathrm{CO}_{3}$ serta limbah kayu sisa dekortikasi rami yang diperoleh dari Sentra Industri Rami dari Desa Wanaraja Kabupaten Garut dan limbah cangkang kulit kopi yang diperoleh dari Desa Pangalengan Kabupaten Bandung. 


\subsection{Analisis Sampel}

Uji kualitas dari karakteristik bahan baku rami dan kulit kopi dengan menggunakan standar ASTM dengan parameter analisis nilai kalor (ASTM D5865-13), analisis kadar air (ASTM D 3302-12), volatile matters (ASTM D 3175-11), kadar abu (ASTM D 3175-11), fixed carbon (ASTM D 5142), analisis ultimat(ASTM D 5373). Analisis selulosa dan lignin berdasarkan metode Chesson (Chesson, 1981).

Sampel gas dari proses gasifikasi akan dianalisis komposisi gasnya dengan menggunakan gas analyzer.

\subsection{Peralatan Pengujian}

Peralatan pengujian tersusun dari reaktor gasifikasi, cyclone, syn-gas cooler, blower dan flare gas, serta dlengkapi dengan gas analyzer seperti ditunjukkan pada Gambar 1. Reaktor dibuat dari plat besi stainlessteel yang mampu menahan suhu sampai $1100{ }^{\circ} \mathrm{C}$ dengan geometri bagian dasar menyempit (throat system). Dimensi reaktor adalah tinggi $1,5 \mathrm{~m}$, dan diameter dalam $0,40 \mathrm{~m}$. Di bagian bawah terdapat grate tempat meletakkan serpihan kayu sebagai pemicu awal penyalaan dalam proses gasifikasi tersebut.

\subsection{Metode Penelitian}

Penelitian dilakukan secara eksploratif deskriptif terhadap komposisi lignin dan selulosa serta proksimat dan ultimat biomassa dari sampel dan mengaplikasikannya pada proses gasifikasi untuk dapat diamati karakteristik gas yang dihasilkan. Bahan baku untuk proses gasifikasi berupa

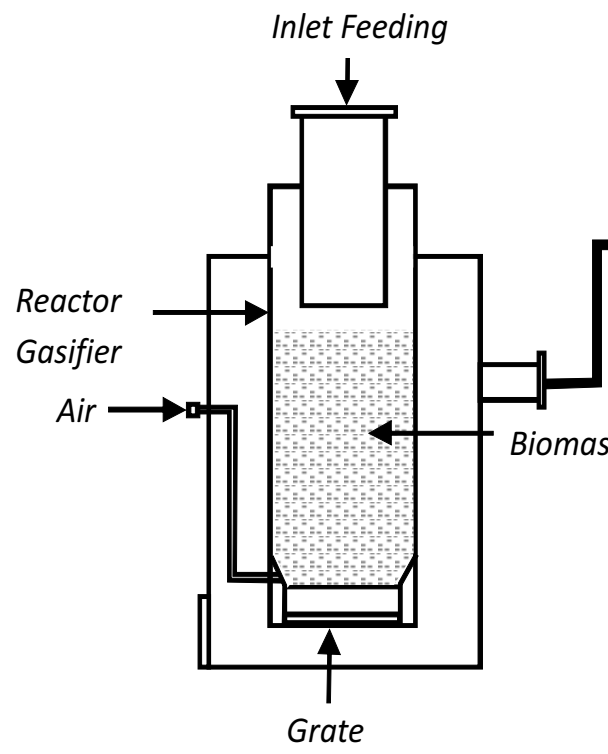

\section{Gas Cleaning}

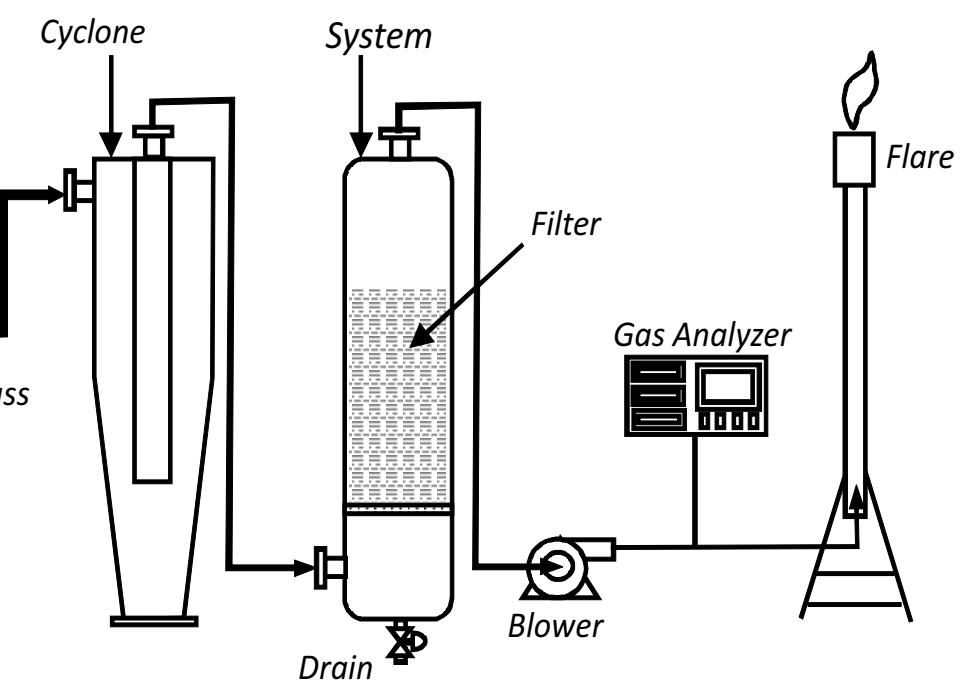

Gambar 1. Skematik peralatan gasifikasi downdraft

masing-masing variasi komposisi yaitu Rami $100 \%$, Cangkang Kulit Kopi 100\%, dan campuran Rami 50\%+Cangkang Kulit Kopi 50\%.

Prosedur awal dari proses gasifikasi adalah memasukkan bahan baku yang akan digasifikasi ke dalam tabung reaktor seberat $11 \mathrm{~kg}$. Blower dinyalakan sebelum melakukan proses pembakaran bahan bakar didalam reactor gasifier. Kemudian biomasa ditambahkan ke dalam reactor sesuai dengan jumlah yang direncanakan. Udara pembakaran diatur sedemikian rupa sehingga udara pembakaran dibawah stoikiometri dan prosesnya merupakan proses pembakaran tidak sempurna. Dari pembakaran tidak sempurna tersebut akan menghasilkan gas yang masih mampu dibakar yaitu gas $\mathrm{CO}, \mathrm{H}_{2}$ dan $\mathrm{CH}_{4}$. Karena isapan dari blower, maka gas tersebut akan mengalir melalui cyclone. Pada tabung cyclone terjadi pemisahan sebagian besar abu halus, sebagian fraksi berat lainnya (tar) dengan gas mampu bakar. Gas yang keluar dari cyclone akan mengalir memasuki gas cleaning system yang memisahkan antara tar dan gas hingga tar akan jatuh ke penampung tar. Gas yang relative bersih akan di salurkan ke pipa flare gas untuk dibakar. Selama proses gasifikasi dilakukan, selama proses dalam kondisi stabil dengan dipantau menggunakan gas analyzer secara online. Analisis komposisi gas dilakukan secara bersamaan dengan proses gasifikasi. Parameter yang diamati yaitu kadar hidrogen, karbon dioksida, karbon monoksida, metana, dan nitrogen. Selain itu juga akan diperoleh nilai kalor gas yang akan digunakan untuk perhitungan mendapatkan energi listrik.

Setelah berlangsung selama \pm 3 jam, dimana data konsentrasi gas yang diukur sudah tidak menunjukan penambahan, maka proses gasifikasi dihentikan. Data yang terkumpul selanjutnya akan dianalisis secara deskriptif dalam bentuk tabel dan grafik. 


\section{HASILDAN PEMBAHASAN}

\subsection{Karakteristik Bahan baku}

Hasil dari uji karakteristik bahan baku ditampilkan pada Tabel 1. Uji proksimat menunjukan bahwa kadar air dari bahan baku masing-masing adalah sebagai berikut. Kandungan air dari sampel cangkang kulit kopi memiliki kadar 23,35\% , menunjukkan kadar yang lebih tinggi dibandingkan bahan chip kayu rami yang memiliki kadar 11,49\%. Kondisi ini diperoleh dari chip kayu rami yang mengalami masa penyimpanan lebih lama dibandingkan cangkang kulit kopi, sehingga kadar air yang terhitung merupakan kadar air bawaan (moisture regain). Pencampuran biomassa sebanyak 1: 1 antara cangkang kopi dan chip kayu rami dapat menaikkan kadar air biomassa rami menjadi $17 \%$.Kandungan zat menguap atau volatile matter (VM) dari sampel yang dianalisis menunjukkan bahwa hampir $50 \%$ senyawa yang dapat terbakar menjadi zat atau gas-gas : seperti hidrogen, karbon monoksida, dan metana, serta sebagian kecil uap yang dapat mengembun seperti tar, hasil pemecahan termis seperti karbon dioksida dari karbonat, sulfur dari pirit, dan air dari lempung yang hilang bila sampel biomassa dipanaskan pada temperatur $900^{\circ} \mathrm{C}$ selama tujuh menit.

Analisis kadar abu dari cangkang kulit kopi sangat rendah, yaitu sekitar $4,83 \%$, tetapi kadar abu dari chip kayu rami menunjukkan kadar yang cukup tinggi hampir mencapai 40\%. Tingginya kadar abu pada chip kayu rami karena adanya komposisi mineral yang terkandung pada biomassa rami seperti garam-garam organik pektat; garam anorganik seperti garam fosfat, karbonat, klorida, sulfat, nitrat, dan senyawa komplek seperti pektin-Ca. Hasil pencampuran biomassa cangkang kopi dan chip kayu rami ternyata dapat meningkatkan proses pelepasan zat mudah menguap sehingga menyisakan abu dengan kadar yang lebih rendah.

Karbon terikat (fixed carbon) adalah fraksi karbon yang terikat di dalam komponen sampel selain fraksi abu, air, dan zat menguap. Kadar karbon pada ketiga sampel yang dianalisis menunjukkan nilai karbon terikat cukup rendah yaitu pada rentang sekitar $8-13 \%$, kondisi ini kemungkinan disebabkan baik pada cangkang kulit kopi dan chip kayu rami komposisi yang utama lebih didominasi oleh komponen mineral yang mudah menguap.

Hasil analisa ultimat, kadar elemen karbon (C) pada cangkang kulit kopi lebih tinggi nilainya dari chips kayu rami maupun campurannya, hal ini dikarenakan kandungan organik (lignin dan selulosa) pada cangkang kulit kopi lebih tinggi nilainya. Kandungan nitrogen dari biomassa merupakan hal yang signifikan, khususnya dengan hubungan polusi udara, jadi suatu biomassa dengan nitrogen yang rendah lebih diharapkan pada industri. Suatu sumber bahan bakar sebaiknya tidak boleh mengandung kadar nitrogen lebih dari 3 \% (Davidson, 1994). Hasil analisis kadar $\mathrm{N}$ dari biomassa cangkang kopi dan chip kayu rami ataupun campurannya adalah sekitar $1,3-1,9 \%$, sehingga kualitas biomassa yang digunakan memehuni kualitas sebagai sumber energi yang rendah polusi. Sulfur menyebabkan polusi udara ketika dikeluarkan ke lingkungan. Cangkang kulit kopi tidak menunjukkan adanya senyawa sulfur, tetapi chip kayu rami menujukkan adanya senyawa sulfur sekitar $0,075 \%$ dan cenderung menurun menjadi $0,018 \%$ bila diformulasikan dalam bentuk campuran biomassa. Adanya komponen sulfur pada rami kemungkinan dapat berbentuk sulfur organik yang ada pada senyawa organik atau mineral sulfat, biasanya hydrous iron atau kalsium sulfat yang dihasilkan dari oksidasi fraksi sulfide pada komponen biomassa.

Nilai kalor merupakan salah satu indikasi kualitas biomassa untuk dijadikan bahan bakar agar memenuhi panas yang diperlukan. Semakin tinggi nilai kalor, semakin baik kualitas bakar yang dihasilkan (Majoumerd,2016). Gambar 2 menampilkan hasil analisis nilai kalor untuk bahan baku.

Tabel 1. Hasil analisis bahan baku

\begin{tabular}{lcccc}
\hline $\begin{array}{c}\text { Parameter } \\
\text { Analisis }\end{array}$ & $\begin{array}{c}\text { Cangkang Kulit } \\
\text { Kopi }\end{array}$ & $\begin{array}{c}\text { Chip Kayu } \\
\text { Rami }\end{array}$ & $\begin{array}{c}\text { Cangkang Kulit } \\
\text { Kopi 50\%+Chip } \\
\text { Kayu Rami 50\% }\end{array}$ & Satuan \\
\hline Proksimat & 23,35 & 11,49 & 17,04 & $\% W$ \\
Moisture & 4,83 & 37,73 & 21,13 & $\% W$ \\
Ash & 58,77 & 42,22 & 49,90 & $\% W$ \\
Volatile matter & 13,06 & 8,57 & 11,93 & $\% W$ \\
Fixed carbon & & & & \\
Ultimat & 34,22 & 23,64 & 29,38 & $\% W$ \\
Carbon (C) & 6,46 & 4,20 & 5,38 & $\% W$ \\
Hydrogen (H) & 1,93 & 1,80 & 1,33 & $\% W$ \\
Nitrogen $(N)$ & 0,000 & 0,075 & 0,018 & $\% W$ \\
Sulfur (S) & & & & \\
\hline
\end{tabular}




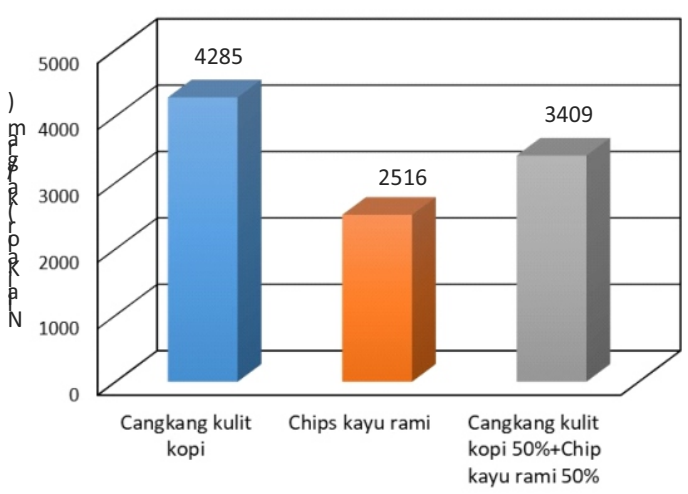

Gambar 2. Nilai kalor dari bahan baku

Biomassa chip kayu rami menunjukkan nilai kalor yang terendah yaitu sekitar $2516 \mathrm{kkal} / \mathrm{kg}$, tetapi nilai kalor untuk cangkang kulit kopi sekitar $4285 \mathrm{kkal} / \mathrm{kg}$. Bila kedua biomassa tersebut dicampurkan dengan rasio $1: 1$, maka nilai kalor yang diperoleh menjadi sekitar $3409 \mathrm{kkal} / \mathrm{kg}$. Perubahan nilai kalor dari kondisi biomassa tunggal (murni tanpa campuran) kemungkinan disebabkan oleh adanya perubahan komposisi air, abu, zat menguap, dan karbon terikatnya yang ada di biomassa campuran.

\subsection{Komposisi Lignin dan Selulosa}

Komposisi lignin dan selulosa dalam suatu biomassa dapat diketahui melalui analisis lignin dan selulosa secara kimia di laboratorium.

Tabel 2. Komposisi Lignin dan Selulosa pada bahan baku

\begin{tabular}{lcc}
\hline \multicolumn{1}{c}{ Bahan Baku } & $\begin{array}{c}\text { Lignin } \\
\mathbf{\%}\end{array}$ & $\begin{array}{c}\text { Selulosa } \\
\mathbf{\%}\end{array}$ \\
\hline Cangkang kulit kopi & 45,10 & 17,93 \\
Chips kayu rami & 18,26 & 44,82 \\
$\begin{array}{l}\text { Cangkang kulit kopi } \\
\text { 50\%+Chip kayu rami }\end{array}$ & 21,74 & 35,96 \\
$50 \%$ & & \\
\hline
\end{tabular}

Hasil analisis lignin dan selulosa masingmasing biomassa dapat dilihat melalui grafik pada Tabel 2. Berdasarkan hasil analisis, biomassa cangkang kulit kopi memiliki kandungan lignin $45,10 \%$, sedangkan chip kayu rami $18,26 \%$. Campuran dari keduanya dengan perbandingan $1: 1$ mengandung lignin $21,74 \%$. Cangkang kulit kopi memiliki kandungan lignin terbesar namun selulosa kebalikannya dengan kandungan terendah. Hal ini juga berlaku untuk chips kayu rami.

\subsection{Komposisi Gas Hasil Uji Gasifikasi}

Proses dekomposisi lignin mulai terjadi pada tahapan pirolisis yang merupakan salah satu tahapan dalam gasifikasi. Lignin terdekomposisi secara perlahan pada interval temperature yang lebih luas daripada selulosa, yakni $200^{\circ} \mathrm{C}-500^{\circ} \mathrm{C}$. Proses dekomposisi lignin berakhir pada temperatur $800^{\circ} \mathrm{C}$ (Giudicianni et al, 2013). Hasil gasifikasi tersebut, yakni berupa gas bakar dengan komposisi ditampilkan pada Tabel 3. Gas $\mathrm{CO}, \mathrm{H}_{2}$, dan $\mathrm{CH}_{4}$ merupakan gas-gas yang paling penting dihasilkan dari proses gasifikasi.Gas-gas tersebut dihasilkan dari reaksi karbon yang terjadi di dalam reaktor.

\begin{tabular}{cccc}
$\begin{array}{c}\text { Gas } \\
\text { Mampu } \\
\text { Bakar }\end{array}$ & $\begin{array}{c}\text { Cangkang } \\
\text { Kulit Kopi }\end{array}$ & $\begin{array}{c}\text { Chip } \\
\text { Kayu } \\
\text { Rami }\end{array}$ & $\begin{array}{c}\text { Cangkang } \\
\text { kulit kopi } \\
\mathbf{5 0 \% +} \\
\text { Chip kayu } \\
\text { rami 50\% }\end{array}$ \\
\hline \multicolumn{4}{c}{ \% vol, rata-rata } \\
\hline $\mathrm{CO}$ & 16,08 & 13,83 & 13,86 \\
$\mathrm{CH}_{4}$ & 3,91 & 3,47 & 1,75 \\
$\mathrm{H}_{2}$ & 6,98 & 10,35 & 7,35 \\
$\mathrm{C}_{\mathrm{n}} \mathrm{H}_{\mathrm{m}}$ & 0,15 & 0,21 & 0,48 \\
\hline
\end{tabular}

Gas CO yang terbentuk pada proses gasifikasi cangkang kulit kopi (lignin 45,10\%, selulosa $17,93 \%$ ) lebih tinggi konsentrasinya dibandingkan dengan $\mathrm{CO}$ yang terbentuk dari chips kayu rami (lignin 18,26\%, selulosa 44,82\%). Hal ini karena kadar lignin memiliki rantai karbon yang lebih banyak dibandingkan dengan selulosa (Sjostrom, E. 1991). Sebaliknya untuk konsentrasi gas $H_{2}$ pada chips kayu rami lebih tinggi karena selulosa lebih tinggi (Brebu,2010). Pembentukan $\mathrm{CH}_{4}$ terjadi ketika $\mathrm{C}$ bereaksi dengan $\mathrm{H}_{2}$. Gugus $\mathrm{C}_{\mathrm{n}} \mathrm{H}_{\mathrm{m}}$ adalah gugus hidrokarbon dengan rantai karbon $(\mathrm{C})$ diatas 1 (satu), yang dapat dideteksi oleh gas analyzer.

Konsentrasi gugus $\mathrm{C}_{\mathrm{n}} \mathrm{H}_{\mathrm{m}}$ tidak signifikan dalam proses produksi gas mampu bakar, namun dalam perhitungan untuk memprediksi besar energi dari gas mampu bakar, $\mathrm{C}_{\mathrm{n}} \mathrm{H}_{\mathrm{m}}$ diasumsikan sebagai gas $\mathrm{C}_{2} \mathrm{H}_{2}$. Gas mampu bakar yang dihasilkan pada proses gasifikasi atau gas hasil gasifikasi yang terbentuk berhubungan dengan kadar lignin dan selulosa yang terkandung pada bahan bakunya.

Karbon merupakan materi penyusun gas $\mathrm{CO}$ dan $\mathrm{CH}_{4}$ sekaligus materi penyusun senyawa kompleks pada tumbuhan, diantaranya lignin dan selulosa. Lignin memiliki kandungan karbon yang lebih banyak dibandingkan selulosa (Sjostrom, E. 1991). Cangkang kulit kopi menghasilkan komposisi gas bakar $\left(\mathrm{CO}\right.$ dan $\left.\mathrm{CH}_{4}\right)$ yang lebih tinggi. Hal ini kemungkinan sesuai dengan kandungan lignin dalam biomasssa cangkang kulit kopi. Baik chip kayu rami maupun biomassa campuran memiliki komposisi gas mampu bakar atau gas bakar $\mathrm{CO}$ dan $\mathrm{CH}_{4}$ yang lebih rendah, keadaan ini disebabkan oleh karbon yang terdapat pada biomassa rami dan campuran tidak lebih tinggi dibandingkan cangkang kulit kopi.

Gas yang paling penting untuk digunakan sebagai penghasil listrik yaitu $\mathrm{CO}$ dan $\mathrm{H}_{2}$. 
Komposisi gas bakar dengan nilai kadar hidrogen tertinggi akan cenderung memiliki nilai kalor gas tertinggi (Rajvanshi, 2014). Gas-gas yang dihasilkan berasal dari gugus-gugus dalam struktur lignin. Gas CO dibentuk dari gugus aldehid, sedangkan gas $\mathrm{H}_{2}$ yang terbentuk berasal dari gugus alifatik dan motoksi dari struktur lignin (Palonen, 2004).

\subsection{Potensi Energi Gas Gasifikasi}

Untuk perhitungan prediksi potensi energi dari bahan baku yang dipakai, maka dipakai referensi nilai kalor dari gas mampu bakar low heating value (LHV) pada Tabel 4 (Waldheim and Nilsson, 2001).

Tabel 4. Nilai kalor gas

\begin{tabular}{cc}
\hline GAS & LHV \\
& $\mathrm{kJ} / \mathrm{m}^{3}$ \\
\hline $\mathrm{CO}$ & 12634 \\
$\mathrm{CH}_{4}$ & 35823 \\
$\mathrm{H}_{2}$ & 11800 \\
$\mathrm{C}_{2} \mathrm{H}_{2}$ & 56060 \\
\hline
\end{tabular}

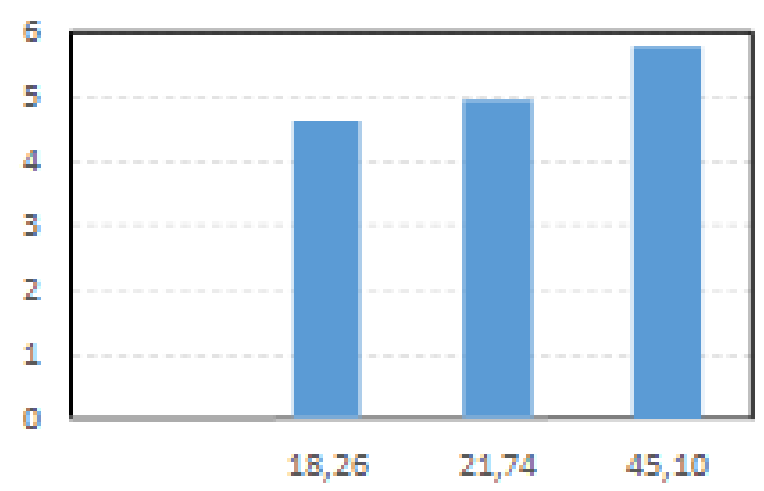

Gambar 3. Korelasi kadar lignin dengan energi gas hasil gasifikasi.

Dengan memakai informasi dari Table 4, maka dapat dihitung energi gas mampu bakar. Adapun korelasi energi gas mampu bakar yang dihasilkan terhadap kandungan lignin adalah sebagai pada Gambar 3 diatas.

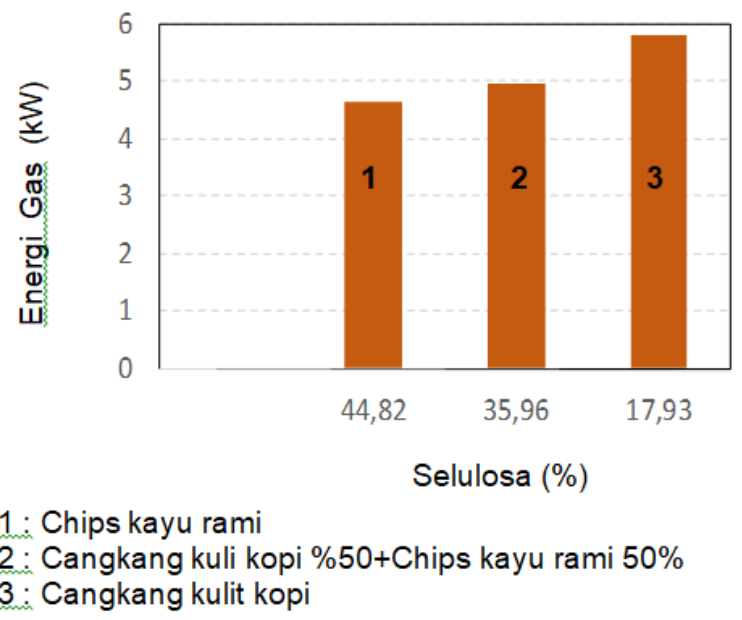

Gambar 4. Korelasi kadar selulosa dengan energi gas hasil gasifikasi.
Pada diagram diatas terlihat bahwa kadar lignin tinggi memiliki potensi energi yang tinggi seperti yang ditunjukn pada bahan cangkang kulit kopi. Sedangkan potensi energi yang rendah terjadi pada gas mampu bakar untuk chips kayu rami dengan kadar lignin rendah. Hal ini sesuai dengan penelitian yang dilakukan oleh Barmina et al., 2013. Untuk korelasi antara kadar selulosa dengan energi gas ditampilkan pada Gambar 4 diatas.

Untuk bahan baku dengan kadar selulosa tinggi menghasilkan potensi energi yang lebih renda seperti yang ditunjukan pada Gambar 4 dan sesuai dengan penelitian yang dilakukan oleh Brebu \& Vasile, 2010.

\section{KESIMPULAN}

Kesimpulan yang didapatkan berdasarkan penelitian yang telah dilakukan adalah dimana limbah cangkang kulit kopi dan chips kayu rami dimanfaatkan menjadi sumber energi baru untuk menghasilkan syngas dengan cara proses gasifikasi. Kadar lignin tertinggi adalah untuk cangkang kulit kopi $45,10 \%$ dan terendah chips kayu rami 18,26. Sedangkan kadar selulosa tertinggi adalah chips kayu rami $44,82 \%$ dan terendah adalah cangkang kulit kopi 17,93\%.

Potensi energi yang dihasilkan dari gas hasil gasifikasi memberikan korelasi terhadap kadar lignin dan selulosa. Semakin tinggi kadar lignin dan semakin besar kadar selulosa, maka memberikan energi yang lebih tinggi yang terjadi pada cangkang kulit kopi sebesar 5,78 kW, dan sebaliknya yang terjadi pada chips kayu rami dengan kadar lignin rendah dan kadar selulosa tinggi memberikan potensi energy sebesar 4,64 $\mathrm{kW}$.

\section{DAFTAR PUSTAKA}

Affendi, M., Sugiyatno, Iman, D., dan Haifa, W. 2010. Uji Variasi Beban Listrik dan Rasio Gas Hasil Gasifikasi Sekam Padi Pada Mesin Diesel Dual Fuel. Seminar Rekayasa Kimia dan Proses 2010

Akudo, C. O. and Theegala, C. S. 2014. Quantification of Tars, Particulates, and Higher Heating Value in Gases Produced from a Biomass Gasifier. BioResources 9 (3) : 5627-5635.

Anis, S., Karnowo, Wahyudi, Sri. M. B. R. 2010. Studi Eksperimen Gasifikasi Sekam Padi pada Updraft Circulating Fluidized Bed Gasifier. Jurnal Universitas Negeri Semarang.

Arisanty, Y. R., Yuni, K., dan Annisa, W. U. 2009. Gasifikasi Limbah Kulit Biji Kopi dalam Reaktor Fixed Bed dengan Sistem Inverted Downdraft Gasifier : Distribusi Temperatur. Simposium Nasional RAPI VIII.

Badan Pusat Statistik. 2017. Produksi Perkebunan Per Tahun. Bandung: BPS Provinsi Jawa Barat.

Barmina, I., Agnese, L., Raimonds,V. , and Maija, Z. 2013. Effects Of Biomassa Composition Variations On Gasification and Combustion Characteristics. Engineering for Rural Development.

Brebu, M. and Vasile, C. 2010. Thermal Degradation of Lignin-A 
Review. Cellulose Chemistry and Technology 44 (9) : 353363.

Campbell, I. M. 1983. Biomass, Catalysts, and Liquid Fuels. Technomic Publishing Co., Inc.

Chesson, A. 1981. Effects of Sodium Hydroxide on Cereal Straws in Relation to the Enhanced Degradation of Structural Polysaccharides by Rumen Microorganisms. Journal of Science Food Agriculture. Vol. 32, Hal 745-758.

Davidson, R.M. (1994) "Nitrogen in Coal", IEA Coal Perspectives, January.

Fengel, D dan G. Wagener. 1984. Kayu Kimia, Ultrastruktur, Reaksi-Reaksi. Gadjah Mada University Press. Yogyakarta.

Giudicianni, P., Giuseppe, C., and Raffaele, R. 2013. Cellulose, Hemicellulose and Lignin Slow Steam Pyrolysis: Thermal Decompositionof Biomass Components Mixtures. Journal of Analytical and Applied Pyrolysis 100 (2013) 213-222

Iskandar, T dan Siswati, N. D. 2012. Pemanfaatan Limbah Pertanian Sebagai Energi Alternatif Melalui Konversi Thermal. Buana Sains Vo;.12 No.1:117-122

Jakle, R. 2006. Uji Performansi Downdraft Gasifier (Reaktor Hasifikasi) Biomass Tipe Imbert dengan Gas Cooler sebagai Salah Satu Unit Pemurniannya. [Skripsi] Fakultas Teknologi Pertanian IPB.

Kumar, H., Prashant, B., Pankaj, A., and S. C. Soni. 2014. Effedt of Moisture Content on Gasification Efficiency in Downdraft Gasifier. International Journal of Scientific Engineering and Technology Volume No. 3 Issue No. 4 : 411-413.

Waldheim, L., Nilsson, T., 2001. Heating Value Of Gases From Biomass Gasification: Report prepared for: IEA Bioenergy Agreement, Task 20 - Thermal Gasification of Biomass TPS Termiska Processer. Sweden,May.

Palonen, H., 2004, Role of Lignin in The Enzymatic Hydrolysis of Lignocellulose. VTT Biotechnology, Helsinki University of Technology, Finland.

Parikh, J., Channiwala, S. A., and Ghosal, G. K. 2005. A Correlation for Calculating HHV from Proximate Analysis of Solid Fuels. Elsevier Fuel 84 : 487-494

Purnomo, S.E. 2010. Pembuatan Arang Aktif dari Kulit Biji Kopi dan Aplikasinya sebagai Adsorben Zat Warna Metilen Biru dan Naphtol Yellow. Fakultas Sains dan Teknologi, Universitas Islam Negeri Sunan Kalijaga
Yogyakarta.

Purwati, R. D. 2010. Strategi Pengembangan Rami (Boehmeria nivea Gaud). Perspektif Vol.9 No.2: 106-118.

Rajvanshi, A. K. 2014. Biomass Gasification. Text Book Gasification Research at Nimbar Agricultural Research Institute, India.

Sadaka, Samy. 2006. Gasification. Nevada : Department of Agricultural and Biosystem Engineering Lowa State University.

Simanihuruk, K. dan Sirait. 2010. Silase Kulit Buah Kopi sebagai Pakan Dasar pada Kambing Boerka sedang Tumbuh. Seminar Nasional Teknologi Peternakan dan Veteriner. Sumatera Utara.

Sjostrom, E. 1991. Kimia Kayu Dasar-dasar dan Penggunaan. Terjemahan. Yogyakarta: Gadjah Mada University Press.

Tasma, D., Krisztina, U., and Tanase, P. 2013. The Effect of Excess Air Ratio on Syngas Produced by Gasification of Agricultural Residues Briquettes. Journal University of Galati Romania.

Tasma, D., Tanase, P., Jorge, M., Krisztina, U., and Catalin, M. 2012. Experimental Study of a Downdraft Fixed Bed Gasifier. Journal University of Galati Romania.

Tenaya. I. G. N. P., I. Nyoman. S. W., dan I. Nyiman. E. G. 2015. Genset dengan Bahan Bakar Gasifikasi Downdraft Kulit Kopi dan Batu Bara. Proceeding Seminar Nasional Tahunan Teknik Mesin XIV (SNTTMXIV)

Ummatin, C. dan Alfiarty, A. 2015. Optimalisasi Proses Gasifikasi dari Limbah Kulit Kopi (Coffee robusta) Menjadi Fenol Berupa Asap Cair dengan Variasi dan Ukuran Partikel Bahan. ITN Malang. Journal of Chemical Engginering.

Widyotomo, S. 2013. Potensi Dan Teknologi Diversifikas Limbah Kopi Menjadi Produk Bermutu Dan Bernilai Tambah. Review Penelitian Kopi dan Kakao 1 (1) 2013, 63-80

Wulandari. A. P. 2015. Rami : Prospeksi Serat dan Limbah. Unpad Press. 
